\title{
Testicular Non-Seminomatous Germ Cell Tumor
}

National Cancer Institute

\section{Source}

National Cancer Institute. Testicular Non-Seminomatous Germ Cell Tumor. NCI

Thesaurus. Code C9313.

A testicular germ cell tumor characterized by the absence of a seminomatous component. It includes embryonal carcinoma, yolk sac tumor, choriocarcinoma, teratoma, and mixed forms. 